\title{
Microbial Ecology of Volcanic Sulphidogenesis: Isolation and Characterization of Thermodesulfobacterium commune gen. nov. and sp. nov.
}

\author{
By J. G. ZEIKUS, ${ }^{*}$ M. A. DAWSON, T. E. THOMPSON, K. INGVORSEN $\dagger$ \\ AND E. C. HATCHIKIAN $\ddagger$ \\ Department of Bacteriology, University of Wisconsin, Madison, Wisconsin 53706, U.S.A.
}

(Received 2 June 1982; revised 27 September 1982)

\begin{abstract}
Microbial sulphate reduction was examined in thermal waters, sediments and decomposing algal-bacterial mats associated with volcanic activity in Yellowstone National Park. In vivo radioactive tracer studies which demonstrated biological $\left[{ }^{35} \mathrm{~S}\right]$ sulphide production from $\left.{ }^{35} \mathrm{~S}\right]$ sulphate at temperatures higher than $50^{\circ} \mathrm{C}$ but less than $85^{\circ} \mathrm{C}$, correlated with the presence of a unique sulphate-reducing bacterium. This new species proliferated at temperatures above $45^{\circ} \mathrm{C}$ but below $85^{\circ} \mathrm{C}$, and had an optimum growth temperature of $70^{\circ} \mathrm{C}$. The organism was a small Gram-negative, straight rod which displayed an outer-wall membranous layer in thin sections. This obligate anaerobe utilized pyruvate, lactate or $\mathrm{H}_{2}$ as electron donors and sulphate or thiosulphate as electron acceptors for growth and sulphide formation. Pyruvate alone was fermented during growth to hydrogen, acetic acid and $\mathrm{CO}_{2}$. Cell extracts contained cytochrome $c_{3}$ but lacked a desulphoviridin-type bisulphite reductase. The DNA guanosine plus cytosine content was $34.4 \pm 1.0 \mathrm{~mol} \%$. Other unusual biochemical features of this extreme thermophile are discussed. Strain YSRA-1 is described as the type strain of the new genus and species Thermodesulfobacterium commune.
\end{abstract}

\section{INTRODUCTION}

There has recently been a considerable renewed interest in the biology of obligately thermophilic (caldoactive) bacteria (Brock, 1978; Ljungdahl, 1979; Zeikus, 1979). Most previous studies have concentrated on the ecology and physiology of aerobic thermophiles (Brock, 1978), whereas thermophilic anaerobes are now receiving their just attention (Ljungdahl et al., 1981; Zeikus et al., 1981).

Recently the bacterial species responsible for anaerobic decomposition of biomass in volcanic spring ecosystems with temperatures greater than $60^{\circ} \mathrm{C}$ have been studied (Zeikus et al., 1980). Also, certain thermal spring waters containing volcanic hydrogen were found to be biologically active and to contain populations of Methanobacterium thermoautotrophicum (Zeikus et al., $1980)$. This species was initially isolated from a heat exchanger $\left(>55^{\circ} \mathrm{C}\right)$ of a municipal sewage sludge treatment facility (Zeikus \& Wolfe, 1972). A variety of different sporeforming and nonsporulating saccharide-fermenting anaerobic thermophiles have been described (Zeikus \& $\mathrm{Ng}$, 1982). Several of these species, including Clostridium thermohydrosulfuricum (Hollaus \& Sleytr, 1972), reduced thiosulphate to sulphide but were not capable of dissimilatory sulphate reduction. Recently, a new species, Clostridium thermosulfurogenes, was described that cleaved thiosulphate into elemental sulphur which accumulated in the culture medium as a turbid white precipitate (Schink \& Zeikus, 1983).

† Present address: Swiss Federal Institute of Technology Zürich and Federal Institute for Water Resources and Water Pollution Control (EAWAG), Überlanstr. 133, CH-8600 Dübendorf, Switzerland.

$\ddagger$ Present address: Laboratoire de Chimie Bactérienne, CNRS, 31 Chemin J. Aiguier, 13-Marseille, France. 
Findings of dissimilatory sulphate-reducing bacterial diversity in volcanic hot springs ecosystems have not been reported to the best of our knowledge. Ward \& Olson (1980) compared microbial sulphate reduction and methanogenic activity in an algal-bacterial mat associated with a moderately warm $\left(40-50^{\circ} \mathrm{C}\right)$ thermal spring. Sulphate-reducing species described include the moderate thermophile, Desulfotomaculum nigrificans, and Desulfovibrio thermophilus, an extreme thermophile isolated from deep subsurface petroleum stratum (Rozanova \& Khudyakova, 1974). Recently, Zillig et al. (1981 $a, b)$ have described new isolates of thermoacidophilic sulphur-reducing species of Thermoproteales and Desulfococcaceae.

We report here that microbial sulphate reduction is widespread in hot aquatic environments in Yellowstone National Park. Also, the general properties of a new dissimilatory sulphatereducing species, Thermodesulfobacterium commune are described.

\section{METHODS}

Chemicals, gases, stock solutions and radioactive compounds. All chemicals were of reagent grade. All gases were of pre-purified quality or passed over heated copper filings to remove traces of $\mathrm{O}_{2}$. All stock solutions were prepared, sterilized and stored in $\mathrm{N}_{2}$-gassed serum vials sealed with black rubber stoppers (Bellco Glass Inc., Vineland, N.J., U.S.A.). Additions were made aseptically with glass syringes. Carrier-free ${ }^{35} \mathrm{SO}_{4}{ }^{2-}\left(43 \mathrm{Ci} \mathrm{mg}{ }^{-1} ; 1.59 \mathrm{TBq}^{-1}\right)$ was obtained from New England Nuclear.

Description of field studies. Microbial sulphate-reducing activity was examined in four different sites located throughout Yellowstone National Park. The exact location, the chemical and physical properties and the detection of methanogenic activity were previously described for these sites (Zeikus et al., 1980).

Radioactive ${ }^{35} \mathrm{SO}_{4}^{2-}$ reduction studies and enrichment culture studies were performed in the field, and thermal features were used as in situ incubators. Radiotracer studies were terminated in the field after the desired incubation times by the addition of zinc acetate $(2 \%, \mathrm{w} / \mathrm{v}$ final concentration) and $\mathrm{NaOH}(0.1 \mathrm{~m}$ final concentration). These same additions were used to inhibit biological activity in control experiments. All experimental tubes and all enrichment cultures were returned to the laboratory at ambient temperature for further analysis. All field experiments were performed in duplicate to quadruplicate tubes and the results were averaged. All individual experiments were performed during August-September 1980; all enrichment experiments were originally performed in September-October 1978 and repeated in 1980. All sampling procedures employed the anaerobic techniques previously described for field studies in thermal environments (Zeikus et al., 1980).

Chemical and physical determinations. Temperature was determined with a high-temperature thermistor (Yellow Springs Instrument, Antioch, Ohio, U.S.A.). Sulphide was determined by the method of Pachmayer as modified by Caldwell \& Tiedje (1975). Sulphate was measured by the turbidimetric assay of Tabatabai (1974). D- or L-lactate was measured by the enzymic method of Bergmeyer (1965). $\mathrm{CO}_{2}$ and $\mathrm{H}_{2}$ were quantified by the thermal conductivity detection gas chromatographic procedures of Nelson \& Zeikus (1974). Acetic acid was measured by the flame ionization detection gas chromatographic methods described by Zeikus et al. (1979).

Measurement of the reduction of $\left.{ }^{35} S\right]$ sulphate into $\left.{ }^{35} S\right]$ sulphide was performed via the exact procedures detailed by Ingvorsen et al. (1981) for determination of bacterial sulphate reduction in anoxic water and sediment samples. The rate of sulphate reduction was determined from points taken during a $72 \mathrm{~h}$ time course.

Medium and cultivation conditions. Anaerobic procedures used for cell cultivation and media preparation were as described previously (Zeikus et al., 1980). All media were dispensed (10 ml) into anaerobic pressure tubes (Bellco) containing a $\mathrm{N}_{2} / \mathrm{CO}_{2}(95: 5)$ head space (unless indicated) and were sealed with a butyl rubber bung. Three different media were employed for stock maintenance and experimental studies. Medium 77 described by Postgate (1969) was used for routine stock maintenance and all enrichment culture studies. Medium 77 contained $\left(\mathrm{g} \mathrm{l}^{-1}\right): \mathrm{K}_{2} \mathrm{HPO}_{4}, 0 \cdot 5 ; \mathrm{NH}_{4} \mathrm{Cl}, 1 \cdot 0 ; \mathrm{CaCl}_{2} .2 \mathrm{H}_{2} \mathrm{O}, 0 \cdot 1 ; \mathrm{MgSO}_{4} .7 \mathrm{H}_{2} \mathrm{O}, 0 \cdot 1$; sodium lactate, 5; yeast extract, $1 \cdot 0$; $\mathrm{FeSO}_{4} .7 \mathrm{H}_{2} \mathrm{O}$, 5; sodium thioglycolate, 1.0; and ascorbic acid, 1.0. Modified Medium 77 was used for all experimental studies except growth on hydrogen and it contained half the amount of yeast extract and lacked $\mathrm{FeSO}_{4} \cdot 7 \mathrm{H}_{2} \mathrm{O}$. Except when indicated, $\mathrm{Na}_{2} \mathrm{SO}_{4}$ was added to $0.3 \%(\mathrm{w} / \mathrm{v})$ final concentration. These modifications enabled growth quantification in the absence of a black FeS precipitate. The chemolithotrophic sulphate-reducing (CSR) medium described by Badziong et al. (1978), which contained trace minerals, low phosphate and iron, and high nitrilotriacetic acid, was used for growth studies in culture tubes. CSR medium contained 25 mM-sodium acetate and $0.05 \%$ yeast extract in addition to the basal minerals and vitamins. Tubes were gassed twice during growth with $\mathrm{H}_{2} / \mathrm{CO}_{2}$.

Black colonies were isolated from anaerobic roll tubes (Hungate, 1969) containing Medium 77 and $4 \%(\mathrm{w} / \mathrm{v})$ Difco purified agar. Stock cultures of all strains were prepared from single isolated colonies that proliferated on transfer in Medium 77. All stock cultures were incubated at $60^{\circ} \mathrm{C}$, without shaking unless indicated in the text.

Large quantities of cells were grown at $65^{\circ} \mathrm{C}$ in a New Brunswick Microferm fermenter that contained 121 modified Medium 77 and which was continually gassed under $\mathrm{N}_{2} / \mathrm{CO}_{2}(95: 5)$. Cells were harvested in a Sorvall 
centrifuge equipped with a $\mathrm{KSB}$ continuous flow adapter. Cells were stored as frozen pellets at $-80^{\circ} \mathrm{C}$ until used.

Cultures were routinely checked for contamination by the detection of growth in the complex medium, TYEG, described for growth of saccharolytic thermophiles (Zeikus et al., 1979).

Cellular characterization. A Carl Zeiss photomicroscope was used for all phase-contrast observations including cell size. The methods used for preparing cells for thin sectioning and electron microscopic examination were as described by Hollaus \& Sleytr (1972). Sections were examined on Hitachi HU-1I electron microscope.

DNA was isolated and purified from lysozyme-treated cells by the method of Marmur (1961). DNA base compositions were calculated according to the method of DeLey (1970) in $0.015 \mathrm{M}-\mathrm{NaCl}$ and $0.0015 \mathrm{M}$-trisodium citrate as determined in a Gilford Model 250 spectrophotometer equipped with a Model 2527 thermoprogrammer. Escherichia coli DNA from Sigma served as standard. DNA base composition values reported represent the mean of three separate determinations. The $\mathrm{G}+\mathrm{C}$ content of the $E$. coli standard was $53.9 \pm 1.0 \%$.

Cytochromes were identified in air versus dithionite-reduced difference spectra of crude cell extracts. The absorption spectra reported here are those on cytochrome $c_{3}$ partially purified as follows. Cells were suspended in $10 \mathrm{~mm}$-Tris/ $\mathrm{HCl}$ buffer ( $\mathrm{pH} \mathrm{7.6)}$ and disrupted by passage through the French pressure cell at $48300 \mathrm{kPa}$. The disrupted cells were centrifuged at $35000 \mathrm{~g}$ for $20 \mathrm{~min}$, the pellet discarded, and the supernatant recentrifuged at $198000 \mathrm{~g}$ for $2 \mathrm{~h}$. The crude proteins in this high-speed supernatant were applied on a silica gel column (Kieselgel $60 \mathrm{~F}_{254}$, type 6 ; Merck) $(1.2 \mathrm{~cm}$ diameter $\times 3 \mathrm{~cm}$ height). After removing unadsorbed proteins with $10 \mathrm{mM}-$

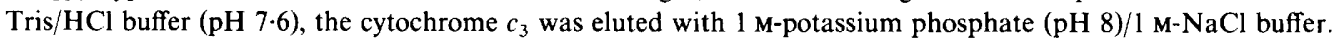
The spectra were performed with a sample of the eluate diluted tenfold in $100 \mathrm{~mm}-\mathrm{Tris} / \mathrm{HCl}(\mathrm{pH} 7 \cdot 6)$. The absorption spectrum was measured with a model 810 Kontron spectrophotometer. Desulfoviridin was examined in cell extracts as reported previously (Badziong et al., 1978).

Growth and metabolic characterization. Growth was determined by measuring the increase in turbidity at $660 \mathrm{~nm}$. Absorbance was estimated directly by insertion of the anaerobic culture tubes into a Spectronic 20 spectrophotometer (Bausch \& Lomb).

Fermentation metabolites were measured directly in liquid or gas samples removed from the culture tubes by syringe. The methods used for quantification of metabolites are described above under chemical determinations.

\section{RESULTS}

\section{Characterization of in situ sulphidogenesis}

Microbial sulphate reduction at high temperatures was studied at several sites in Yellowstone National Park. The specific sites were chosen on the basis of previously demonstrated bacterial activity, or in the case of Ink Pot Spring because its black thermal waters were not methanogenic but contained high concentrations of hydrogen, sulphate and reduced iron (Zeikus et al., 1980). Table 1 compares the rate of biological sulphate reduction at four different sites. (Controls that contained inhibitors of biological activity did not show sulphate-reducing activity.) Sulphate reduction was most active in the decomposing bacterial-algal mat of Octopus Spring. Previous studies by Doemel \& Brock (1977) suggested biological sulphate-reducing activity in this ecosystem where biomass is produced and decomposed by thermophilic micro-organisms. Microbial sulphate-reducing activity was nearly equivalent in the edge sediments of Washburn Pool A or Ink Pot Spring. Notably, biological sulphate-reducing activity was close to the limits of detection in Ink Pot Spring waters when the procedures were employed at 41 or $83^{\circ} \mathrm{C}$, but was observed when the incubations were performed at $70^{\circ} \mathrm{C}$.

Enrichment cultures were initiated with Medium 77 and source inoculum from each site listed in Table 1. After incubation of all enrichments for $6 \mathrm{~d}$ at in situ temperature, the cultures formed a dense black precipitate. Repeated transfer of enrichments revealed small rod-shaped sulphatereducing bacteria in all cultures. Different strains were assigned to isolates obtained from the different sites. All strains appeared morphologically identical when cultured on Medium 77 at $65^{\circ} \mathrm{C}$. Stock cultures were maintained on Medium 77 and transferred monthly. Liquid cultures retained viability after several months storage at room temperature. Only strain YSRA-1 was studied in the complete detail described below.

\section{Cellular properties of $T$. commune}

Cells appeared as very tiny $(0.3 \times 0.9 \mu \mathrm{m})$ straight rods. Cells were often paired and small 'blebs' were observed in all cultures at cell ends or between two paired cells (Fig. 1). Spores, cysts 
Table 1. Relation of volcanic feature to microbial sulphidogenic activity

Site

Octopus Spring

algal mat

Washburn Pool A

edge sediment

Firehole Pool A

edge sediment

Ink Pot Spring

edge sediment

water
In situ
temperature

$\left({ }^{\circ} \mathrm{C}\right)$

59

50

72

70

83
In situ sulphate concn ( $\mathrm{mol} \mathrm{ml} \mathrm{mol}^{-1}$ )
In vivo rate of microbial sulphate reduction* (nmol $\mathrm{SO}_{4}^{2-} \mathrm{ml}^{-1} \mathrm{~d}^{-1}$ )

Sulphidogenic strain isolated

$\begin{array}{ccc}0 \cdot 19 & 91 \cdot 0 \pm 34\left(59^{\circ} \mathrm{C}\right) & \text { YSRB } \\ 10 \cdot 0 & 6 \cdot 0 \pm 2\left(50^{\circ} \mathrm{C}\right) & \text { YSRC } \\ - & - & \text { YSRD } \\ & & \\ 17 \cdot 8 & 6 \cdot 5 \pm 2 \cdot 0\left(70^{\circ} \mathrm{C}\right) & \text { YSRA-1 } \\ 17 \cdot 8 & 0 \cdot 0-0 \cdot 2\left(83^{\circ} \mathrm{C}\right) & \text { YSRA-2 } \\ & 3 \cdot 0 \pm 2 \cdot 0\left(70^{\circ} \mathrm{C}\right) & \\ & 0 \cdot 0-0 \cdot 2\left(41^{\circ} \mathrm{C}\right) & \end{array}$

* To obtain the rate of sulphate reduction per dry wt of mat multiply by 40 .

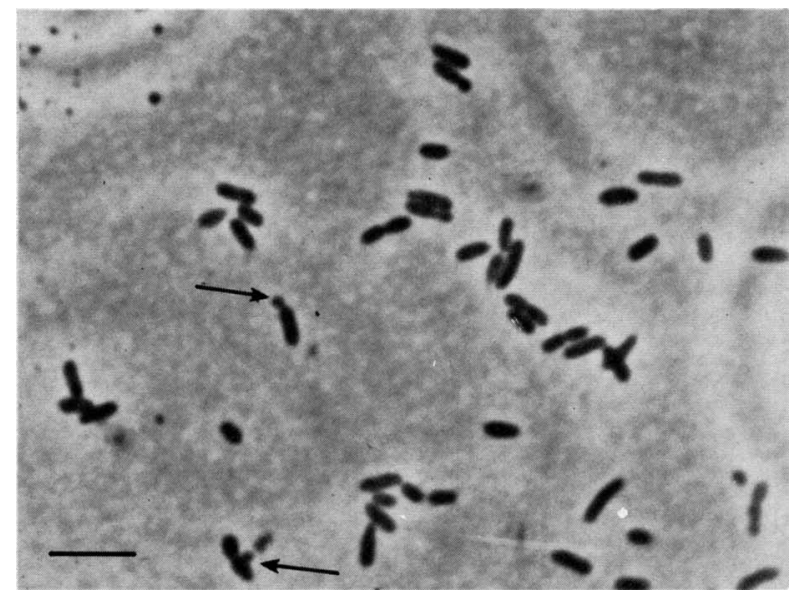

Fig. 1. Phase-contrast photomicrograph of exponential phase cells of T. commune. Arrows point to cell blebs associated with single or dividing cells. The bar marker represents $2 \mu \mathrm{m}$.

and motility were not observed when cultures were examined by phase microscopy. Exponential phase cells stained Gram-negative and lacked catalase. Cell proliferation was not detected in the presence of: chloramphenicol, tetracycline, cycloserine or penicillin $\mathrm{G}$ (each at $100 \mu \mathrm{g} \mathrm{ml}^{-1}$ ); $\mathrm{NaCl}(2 \%)$; and sodium azide $\left(250 \mu \mathrm{g} \mathrm{ml}^{-1}\right)$. Notably, $100 \mu \mathrm{g}$ streptomycin $\mathrm{ml}^{-1}$ did not inhibit growth, but inhibited control cultures of Thermoanaerobium brockii.

In thin sections observed by electron microscopy, cells displayed a typical Gram-negative cell wall architecture (Fig. 2). The outer wall and cytoplasmic membranes were easily discernible, but an inner wall layer was not readily detectable in most cells. Mesosomes (internal membranous bodies) and dense granular inclusions which appeared similar to storage bodies were also visible in cells. Notably, cell material resembling the 'blebs' under phase microscopy appeared to form as extrusions near the outer membranous layer and during cell division (Figs $2 a, 3)$.

DNA isolated from $T$. commune had a base composition of $34.4 \pm 1.0 \%$ guanosine plus cytosine. Difference spectra of crude cell extracts displayed a type $c_{3}$ cytochrome. Figure 4 compares the oxidized and reduced absorption spectrum of cytochrome $c_{3}$ partially purified from $T$. commune. A Soret peak at $409 \mathrm{~nm}$ was observed in the oxidized state, whereas in the reduced state the Soret, beta and alpha peaks were at 419,523 , and $552 \mathrm{~nm}$, respectively: cells did not fluoresce red under alkaline conditions and cell extracts did not display spectral properties of desulphoviridin. 

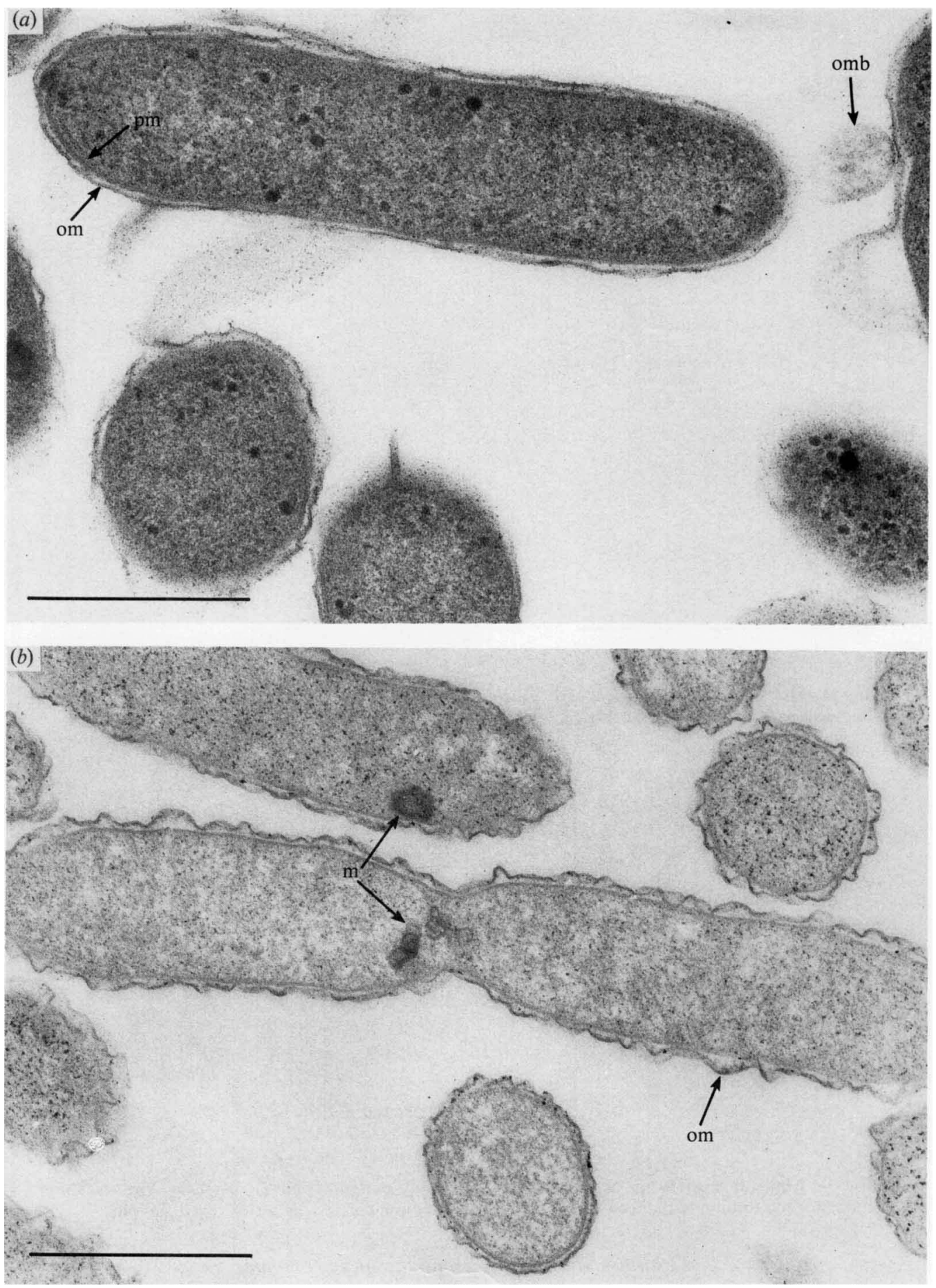

Fig. 2. Electron photomicrograph of thin sections of $T$. commune. (a) Cells displaying the outer membranous wall layer (om), the cytoplasmic membrane (pm) and cellular extrusions or blebs (omb) formed next to the outer membranous layer. Electron-dense granules which appear cytologically similar to storage material are present. (b) Thin sections illustrating cell division mechanism and the presence of internal membranes $(\mathrm{m})$. The bar markers represent $0.5 \mu \mathrm{m}$. 


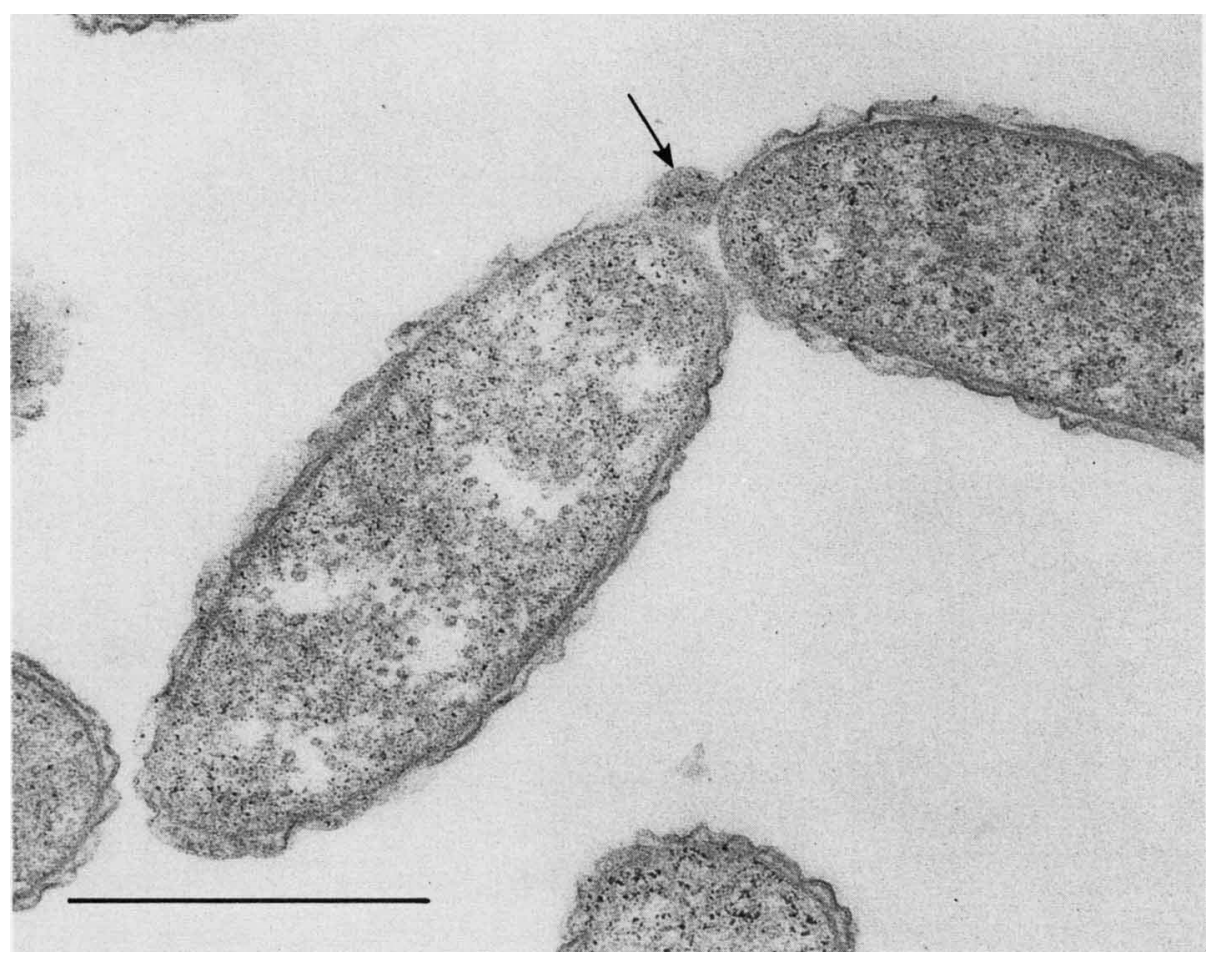

Fig. 3. Electron photomicrograph of $T$. commune showing the presence of bleb or extrusion between two cells (arrow). The bar marker represents $0.5 \mu \mathrm{m}$.

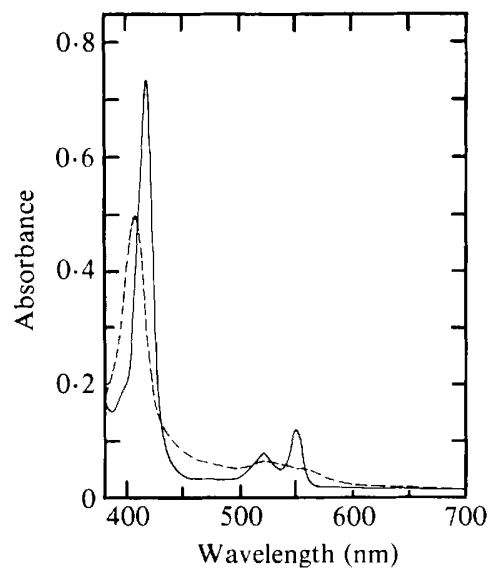

Fig. 4. Absorption spectrum of cytochrome $c_{3}$ partially purified from $T$. commune. The solid line indicates the dithionite-reduced sample. The broken line indicates the air-oxidized sample.

\section{Growth and metabolic properties of T. commune}

The temperature dependence of growth is shown in Fig. 5. Thermodesulfobacterium commune was an obligately caldoactive bacterium with an optimal growth temperature near $70^{\circ} \mathrm{C}$; it grew below $85^{\circ} \mathrm{C}$ and above $45^{\circ} \mathrm{C}$. A typical growth curve of the organism on lactate as energy source is shown in Fig. 6. A long lag period was not observed when an exponential phase culture was used as an inoculum for pre-heated medium. A doubling time of less than $4 \mathrm{~h}$ was observed during the exponential growth phase. The growth rate declined after this period and growth 


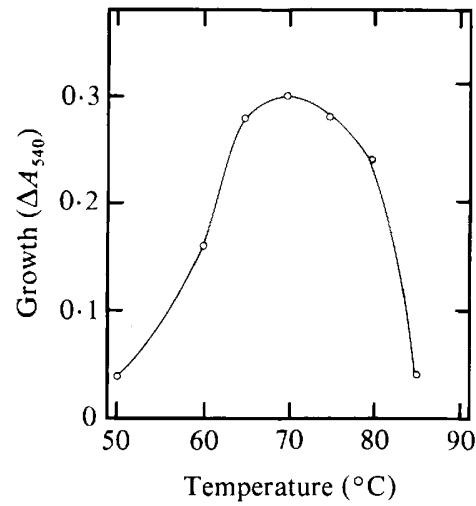

Fig. 5

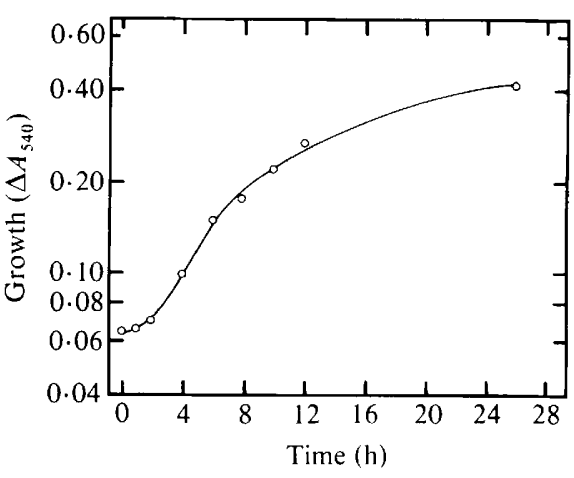

Fig. 6

Fig. 5. Relationship between temperature and growth yield of $T$. commune. The organism was cultured for $72 \mathrm{~h}$ on lactate plus sulphate in modified Medium 77 at the temperatures indicated.

Fig. 6. Growth curve of $T$. commune cultured on lactate plus sulphate in modified Medium 77 at $70^{\circ} \mathrm{C}$.

Table 2. Comparison of growth substrates in the presence or absence of oxidized sulphur species

All experiments were performed in anaerobic culture tubes that contained $10 \mathrm{ml}$ of modified Medium 77, or CSR medium when $\mathrm{H}_{2}$ was used. $25 \mathrm{~mm}$-sodium sulphate or thiosulphate was added where indicated. Results represent the final absorbance for the second transfer on the substrates indicated. Tubes were incubated at $70^{\circ} \mathrm{C}$ without shaking.

\begin{tabular}{|c|c|c|c|}
\hline \multirow[b]{2}{*}{ Growth substrate } & \multicolumn{3}{|c|}{ Growth $\left(\Delta A_{540}\right)$} \\
\hline & Alone & $\begin{array}{c}\text { With } \\
\text { sulphate }\end{array}$ & $\begin{array}{c}\text { With } \\
\text { thiosulphate }\end{array}$ \\
\hline Lactate & 0.01 & $0 \cdot 38$ & $0 \cdot 34$ \\
\hline Pyruvate & 0.25 & $0 \cdot 39$ & $0 \cdot 36$ \\
\hline Glucose & $<0.01$ & $<0.01$ & $<0.01$ \\
\hline Malate & $<0.01$ & $<0.01$ & $<0.01$ \\
\hline Ethanol & $<0.01$ & $<0.01$ & $<0.01$ \\
\hline $\mathrm{H}_{2} / \mathrm{CO}_{2} /$ acetate & $<0.01$ & 0.08 & ND \\
\hline
\end{tabular}

ND, Not determined.

became linear, presumably because of sulphide toxicity (Postgate, 1969). Thermodesulfobacterium commune showed a narrow $\mathrm{pH}$ range of 6.0 to 8.0 for growth in Medium 77 with an optimal $\mathrm{pH}$ near $7 \cdot 0$.

Table 2 summarizes the results of experiments in which different substrates were tested for their ability to serve as electron donors or electron acceptors for energy metabolism and growth. Pyruvate was the only substrate used for growth in the absence of sulphate or thiosulphate. Other than pyruvate, lactate was the only examined organic compound which was utilized as an energy substrate in the presence of sulphate or thiosulphate. Growth was not detected with lactate when either $25 \mathrm{~mm}$-sodium fumarate, nitrate or sulphite were added as electron acceptor. However, at this concentration only sulphite was toxic to growth on pyruvate. Thermodesulfobacterium commune was adapted to grow on $\mathrm{H}_{2} / \mathrm{CO}_{2} /$ acetate medium by first culturing it for several transfers on pyruvate medium with a $\mathrm{H}_{2} / \mathrm{CO}_{2}$ gas headspace.

Figure 7 illustrates a time course for lactate metabolism with sulphate as electron acceptor. Lactate and sulphate were consumed concomitantly during growth and sulphidogenesis. In addition to sulphide, only acetate and $\mathrm{CO}_{2}$ were detected as significant fermentation products. The data roughly approximated a theoretical stoichiometry of: 2 lactate +1 sulphate $\rightarrow 2$ acetate $+2 \mathrm{CO}_{2}+1$ sulphide. Notably, $\mathrm{H}_{2}$ was detected at the end of growth in other experiments that employed sulphate-limited media. 


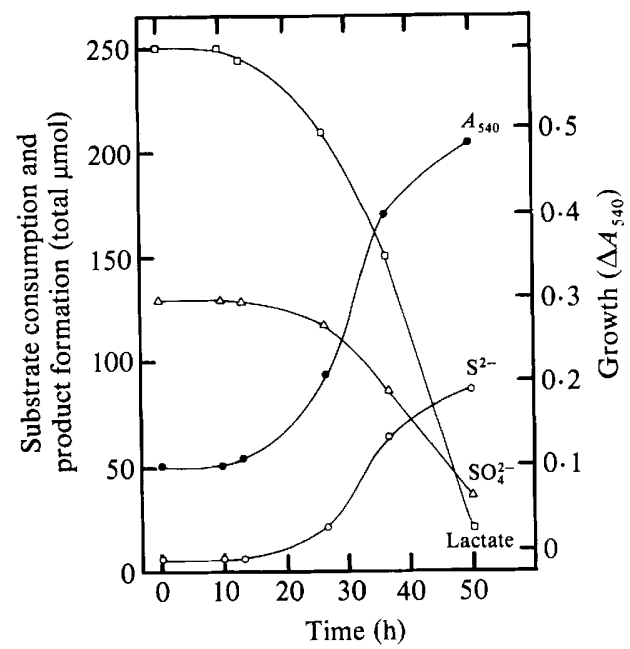

Fig. 7. Fermentation time course for growth of $T$. commune depicting metabolic coupling between lactate oxidation and sulphate reduction to sulphide. The experiment was performed in anaerobic tubes that contained modified Medium 77 and which were incubated at $70^{\circ} \mathrm{C}$.

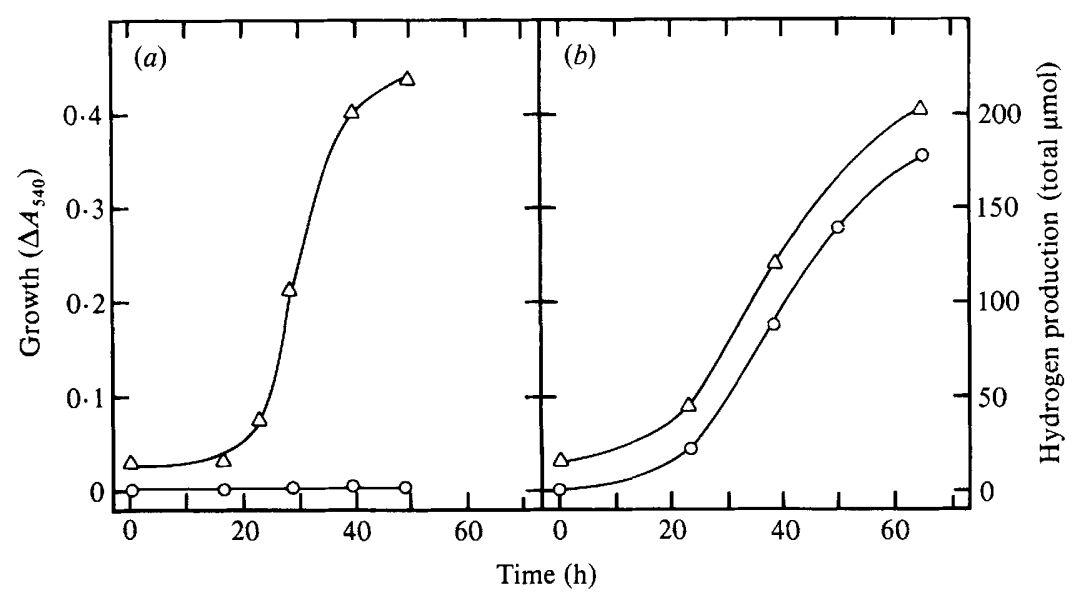

Fig. 8. Comparison of hydrogen metabolism during growth of $T$. commune on pyruvate in the presence (a) or absence $(b)$ of sulphate. Detectability limits for hydrogen were $<0 \cdot 1 \% . \triangle, \Delta A_{540} ; \bigcirc$, hydrogen production.

Figure 8 compares growth and hydrogen production of $T$. commune with pyruvate as energy source. In the absence of sulphate, hydrogen production paralleled growth, but with sulphate $\mathrm{H}_{2}$ was not detectable with the methods employed. At the end of growth on pyruvate alone $198 \mu \mathrm{mol}$ acetate and $203 \mu \mathrm{mol}$ hydrogen were produced. Although $\mathrm{CO}_{2}$ production and pyruvate consumption were not quantified, the results support a theoretical fermentation stoichiometry of: 1 pyruvate $\rightarrow 1$ acetate $+1 \mathrm{H}_{2}+1 \mathrm{CO}_{2}$.

\section{DISCUSSION}

The present study extends the known niche for bacterial dissimilatory sulphate reduction in nature to extreme $\left(>60^{\circ} \mathrm{C}\right)$ thermal environments associated with volcanic activity. Bacterial sulphate reduction at high temperatures appears widespread in Yellowstone National Park and was associated with at least one species, Thermodesulfobacterium commune. Undoubtedly other species remain to be described. Thermodesulfobacterium commune appeared well adapted to the 
thermal features examined, and in Ink Pot Springs the temperature activity profile of in vivo sulphidogenesis correlated with the in vitro growth response of the organism. Thermophilic sulphate-reducing bacteria were found in environments where organic matter was being vigorously decomposed (i.e. the Octopus Spring algal-bacterial mat) or in waters and sediments which contained geothermal hydrogen (i.e. the Ink Pot Hot Spring environment). Sulphidogenesis appeared most active in the sulphate-depleted Octopus Spring Mat algal-bacterial ecosystem, where Doemel \& Brock (1977) previously suggested microbial sulphate reduction occurred. In Yellowstone National Park, where water boils at $92{ }^{\circ} \mathrm{C}$ because of high elevation, microbial sulphate reduction may be limited to temperatures near to where water remains in the liquid state (i.e. near $83^{\circ} \mathrm{C}$ ) as implied by the present studies. Further studies on microbial sulphate reduction in other thermal areas are required to substantiate this observation. In general, life in neutral thermal ecosystems appears limited to niches where water is a liquid (Brock, 1978); however, certain microbial metabolic groups in Yellowstone National Park are not active at extremely high temperatures in nature. In this regard, phototrophic populations have not been observed to proliferate in Yellowstone National Park above $70^{\circ} \mathrm{C}$ and surface methanogens have not been reported active in anaerobic niches above $80^{\circ} \mathrm{C}$.

Thermodesulfobacterium commune extends the known diversity of anaerobic bacteria that perform dissimilatory sulphate reduction (Postgate, 1979; Pfennig \& Widdel, 1981). Several cellular properties suggest $T$. commune is a unique sulphate-reducing species, especially the absence of desulphoviridin and an atypically low DNA guanosine plus cytosine content. Indeed, further detailed biochemical characterization of this species, not reported here, supports this claim. The bisulphite reductase has been purified (C. Hatchikian et al., unpublished), and, although it contains a siroheme as prosthetic group, it is spectrally and catalytically distinct from desulphoviridin, desulphorubidin or P582 type bisulphite reductases (Thauer \& Badziong, 1981). The inhibition of growth by eubacterial-type antibiotics suggests that $T$. commune is not an archaebacterium (Woese et al., 1978). The lipids of $T$. commune have been shown to comprise unique non-isoprenoid branched glycerol diethers and monoethers that have not previously been detected in other organisms (T. Langeworthy et al., unpublished).

Thermodesulfobacterium commune has a limited range of electron donors for growth when compared to other described sulphate-reducing species (Postgate 1979, Pfennig \& Widdel, 1981). The ability of this species to use $\mathrm{H}_{2}$ as an electron donor for growth further supports the general utilization of hydrogen as an energy source for sulphate-reducing bacteria (Badziong $e t$ al., 1978; Brandis \& Thauer, 1981). Hydrogen was also the major reduced end-product of pyruvate fermentation by $T$. commune and it was also detected in low quantities when cultures were grown on lactate plus sulphate. Hydrogen was previously reported as a trace gas formed by lactate-grown sulphate-reducing bacteria (Hatchikian et al., 1976). However, further studies are required to determine if this phenomenon is of major physiological significance as suggested by Tsuji \& Yagi (1980) and Odom \& Peck (1981). The cellular properties of $T$. commune are distinct from other described thermophilic sulphate-reducing bacteria. Unlike Desulfotomaculum nigrificans strains that grow at $55^{\circ} \mathrm{C}$ (Postgate 1979), T. commune is Gram-negative, does not form spores and does not contain a P582-type bisulphite reductase. Desulfovibrio thermophilus differs from $T$. commune because the former species is curved, motile, and contains a desulphoviridin-type bisulphite reductase (Rozanova \& Khudyakova, 1974). Therefore, it appears necessary to establish a new genus and species for the small rod-shaped sulphatereducing bacteria that display an outer wall membrane layer, have a low DNA G + C content of $34 \%$, grow optimally above $60^{\circ} \mathrm{C}$ and lack desulphoviridin, desulphorubidin or P582-type bisulphite reductases. Strain YSRA-1 was most intensively studied and is the type strain of the new genus and species Thermodesulfobacterium commune. The type strain is available from the American Type Culture Collection, Rockville, Md., U.S.A. (ATCC 33706) and the Deutsche Sammlung von Mikroorganismen (DSM 2178).

\section{Genus Thermodesulfobacterium gen. nov.}

Thermo.de.sulfo.bacterium. Gr. n. thermos heat; L. pref. de from; L.n. sulfo sulphur; Gr. n. bakterion a small rod. 
Straight rod-shaped cells, $0.3 \times 0.9 \mu \mathrm{m}$, single or in pairs. Cells often form 'blebs' at cell ends. Cells contain an outer wall membrane layer and stain Gram-negative. Contains non-phytanyl ether-linked lipids and does not contain desulphoviridin.

Chemoorganotroph, strict anaerobe, fermentative and dissimilatory sulphate-reducing metabolism, lactate, pyruvate and hydrogen used as electron donor and sulphate or thiosulphate used as electron acceptor for growth.

\section{Thermodesulfobacterium commune sp. nov.}

Com.mu.ne, L.n., widespread.

Tiny rods, $0.3 \times 0.9 \mu \mathrm{m}$, single or in pairs. Cells often form 'blebs' at cell ends. Motility not observed. Lactate, pyruvate and hydrogen used as electron donor and sulphate or thiosulphate used as electron acceptor for growth.

Fumarate and nitrate not reduced. Pyruvate is fermented to $\mathrm{H}_{2}, \mathrm{CO}_{2}$ and acetate as endproducts. Growth with hydrogen as sole electron donor for energy metabolism. Optimum temperature for growth $70^{\circ} \mathrm{C}$. pH range $6 \cdot 0-8 \cdot 0$. DNA base composition $34 \cdot 4 \mathrm{~mol} \% \mathrm{G}+\mathrm{C}$. Desulphoviridin and desulphorubidin not present. Growth inhibited by $2 \% \mathrm{NaCl}, 250 \mu \mathrm{g}$ sodium azide $\mathrm{ml}^{-1}$; penicillin, cycloserine, chloramphenicol and tetracycline (each at $100 \mu \mathrm{g}$ $\mathrm{ml}^{-1}$ ).

Habitat: anaerobic niches associated with volcanic thermal features. Type strain YSRA-1 isolated from Ink Pot Spring, Yellowstone National Park, U.S.A.

This research was supported by the College of Agricultural and Life Sciences, University of Wisconsin and in part by grant DEB 7824071 from NSF and contract EY79-5-EV-2161 from DOE. K. Ingvorsen was supported in part by a grant from the Danish Natural Science Research Council. The taxonomic assignment was aided by access to unpublished findings of $\mathrm{T}$. Langeworthy and $\mathrm{C}$. Hatchikian. We thank P. Hegge for providing outstanding technical assistance during this investigation.

\section{REFERENCES}

Badziong, W., Thauer, R. K. \& Zeikus, J. G. (1978) Isolation and characterization of Desulfovibrio growing on hydrogen plus sulphate as the sole energy source. Archives of Microbiology 116, 41-44.

Bergmeyer, H. U. (1965). Methods of Enzymatic Analysis. Weinheim, F.R.G.: Verlag Chemie.

Brandis, A. \& Thauer, R. K. (1981). Growth of Desulfovibrio species on hydrogen and sulphate as sole energy source. Journal of General Microbiology 126, 249-252.

BROCK, T. D. (1978). Thermophilic microorganisms and life at high temperatures. New York: Springer Verlag.

Caldwell, D. F. \& Tiedje, J. M. (1975). The structure of anaerobic bacterial communities in the hypolimnia of several Michigan Lakes. Canadian Journal of Microbiology 21, 377-385.

DELEY, J. (1970). Reexamination of the association between melting point, buoyant density and the chemical base composition of deoxyribonucleic acid. Journal of Bacteriology 101, 738-754.

Doemel, W. N. \& Brock, T. D. (1977). Structure, growth and decomposition of laminated algal bacterial mats in alkaline hot springs. Applied and Environmental Microbiology 34, 433-452.

Hatchikian, E. C., Chaigneau, M. \& Legall, J. (1976). Analysis of gas production by growing cultures of three species of sulphate-reducing bacteria. In Microbial Production and Utilization of Gases, pp. 109-118. Edited by H. G. Schlegel, N. Pfennig \& G. Gottschalk. Göttingen: E. Goltz.
Hollaus, F. \& Sleytr, A. (1972). On the taxonomy and fine structure of some hyperthermophilic saccharolytic clostridia. Archives of Microbiology 86, 129-146.

Hungate, R. E. (1969). A roll tube method for cultivation of strict anaerobes. Methods in Microbiology 3B, 117-132.

INGVorsen, K., ZeIKus, J. G. \& Brock, T. D. (1981). Dynamics of bacterial sulphate reduction in a eutrophic lake. Applied and Environmental Microbiology 42, 1029-1036.

LuUngDAHL, L. G. (1979). Physiology of thermophilic bacteria. Advances in Microbial Physiology 19, 149 243.

LuUngdahl, L. G., Bryant, F., Carreia, L., Saeki, T. \& WIEGEL, J. (1981). Some aspects of thermophilic and extreme anaerobic microorganisms. In Trends in the Biology of Fermentations for Fuels and Chemicals, pp. 397-420. Edited by A. Hollaender. New York: Plenum Press.

MARMUR, J. (1961). A procedure for the isolation of deoxyribonucleic acid from microorganisms. Journal of Molecular Biology 3, 208-215.

Nelson, D. R. \& ZeIKus, J. G. (1974). Rapid method on the radioisotopic analysis of gaseous end products of anaerobic metabolism. Applied Microbiology 28, 258-261.

ODOM, J. M. \& PECK, H. D. (1981). Hydrogen cycling as a general mechanism for energy coupling in the sulphate reducing bacteria Desulfovibrio sp. FEMS Microbiology Letters 12, 47-50. 
PfenNig, N. \& Widdel, F. (1981). Ecology and physiology of some anaerobic bacteria from the microbial sulphur cycle. In Biology of Inorganic Nitrogen and Sulphur, pp. 169-177. Edited by H. Bothe \& A. Trebst. Berlin: Springer Verlag.

Postgate, J. R. (1969). Media for sulphur bacteria: some amendments. Laboratory Practice 18, 286-294.

Postgate, J. R. (1979). The Sulphate Reducing Bacteria. Cambridge: University Press.

Rozanova, E. P. \& Khudyakova, A. I. (1974). A new nonsporing thermophilic sulphate-reducing organism, Desulfovibrio thermophilus nov. sp. Microbiology 43, 908-912.

Schink, B. \& ZeIKus, J. G. (1983). Clostridium thermosulfurogenes $\mathrm{sp}$. nov. a new thermophile that produces elemental sulphur from thiosulphate. Journal of General Microbiology 129, 1149-1158.

TABaTABaI, M. A. (1974). Determination of sulphate in water samples. Sulfur Institute Journal 10, 11-13.

Thauer, R. K. \& Badziong, W. (1981). Respiration with sulphate as electron acceptor. In Diversity of Bacterial Respiratory Systems, pp. 188-198. Edited by C. J. Knowles. West Palm Beach: CRC Press.

TsuJI, K. \& YAGI, T. (1980). Significance of hydrogen burst from growing cultures of Desulfovibrio vulgaris Miyazahi and the role of hydrogenase and cytochromes in energy production systems. Archives of Microbiology 125, 35-42.

WARD, D. M. \& OLson, G. J. (1980). Terminal processes in the anaerobic degradation of an algalbacterial mat in a high sulphate hot spring. Applied and Environmental Microbiology 40, 67-74.

Woese, C. R., MaGnum, L. J. \& Fox, G. E. (1978). Archaebacteria. Journal of Molecular Evolution 11, 245-252.

ZeIKUS, J. G. (1979). Thermophilic bacteria: ecology, physiology and technology. Enzyme and Microbial Technology 1, 243-252.

Zeikus, J. G. \& NG, T. K. (1982). Thermophilic saccharide fermentation. In Annual Reports of Fermentation Processes, vol. 6. Edited by G. T. Tsao. New York: Academic Press.

Zeikus, J. G. \& Wolfe, R. S. (1972). Methanobacterium thermoautotrophicum $\mathrm{sp}$. nov. an anaerobic, autotrophic extreme thermophile. Journal of Bacteriology 109, 707-713.

Zeikus, J. G., Hegge, P. W. \& Anderson, M. A. (1979). Thermoanaerobium brockii gen. nov and sp. nov. a new chemoorganotrophic caldoactive anaerobic bacterium. Archives of Microbiology 122, 41-48.

Zeikus, J. G., Ben-Bassat, A. \& Hegge, P. W. (1980). Microbiology of methanogenesis in thermal volcanic environments. Journal of Bacteriology 143, 432-440.

Zeikus, J. G., Ben-Bassat, A., Ng, T. K. \& Lamed, R. J. (1981). Thermophilic ethanol fermentations. In Trends in the Biology of Fermentations for Fuels and Chemicals, pp. 397-420. Edited by A. Hollaender. New York: Plenum Press.

Zillig, W., Stetter, K. O., SChäFer, W., Janekovic, D., Wunderl, S., Holz, I. \& Palm, P. (1981a). Thermoproteales: a novel type of extremely thermoacidophilic anaerobic Archaebacteria isolated from Icelandic solfataras. Zentralblatt für Bakteriologie, Parasitenkunde, Infektionskrankheiten und Hygiene (Abteilung I), Originale C2, 205-227.

Zillig, W., Stetter, K. O., Prangishvilli, D., SCHÄFER, W., WuNDERL, S., JANEKovic, D., Holz, I. \& Palm, P. $(1981 b)$. Desulfurococcaceae, the second family of the extremely thermophilic, anaerobic, sulfur-respiring Thermoproteales. Zentralblatt für Bakteriologie, Parasitenkunde, Infektionskrankheiten und Hygiene (Abteilung I), Originale C3, 304-317. 